\title{
The Spirituality of Beheading: Numinous Experience in Headless
}

\author{
Adam Lovasz \\ PhD Student, Philosophy Department, Eötvös Lóránd University, Budapest. \\ Email: adam.lovasz629@yahoo.com
}

Received October 25, 2017; Revised November 17, 2017; Accepted November 30, 2017; Published December o9, 2017.

\begin{abstract}
In my article I seek to uncover the spiritual content underlying the 2015 slasher film, Headless. The film in question portrays a psychotic serial killer who beheads his female victims. Working through the disturbing content, I seek to unpack an "atheology", to use Georges Bataille's expression and argue that we must see beyond the graphic violence to understand the spirituality of the slasher film. Adapting Cleanth Brooks' approach to poetics, I take the film itself as the object of my aesthetic study, as distinct from its broader environment. Objects are self-sufficient realities whose autonomy must be respected. Rudolf Otto's notion of the "numinous" may be of some help in regard to outlining "beheaded" spirituality as it appears in Headless. Violence unveils the flesh, leading to unspeakable revelations that can only be transmitted through darkness and silence. For Otto, experience of the numinous cannot be put into words. Incommunicability pervades Headless, not only because of the unspeakable crimes perpetrated by the killer, but also because of his own muteness. When confronted with the numinous, we are rendered numb by the awe of this vision. This lack of communication serves to build up tension, until the final scene is unleashed upon the viewer. Using Lee Edelman's theory of negative queerness, I make the case that the mute serial killer is a sinthomosexual, in that he disavows participation in heterosexual reproductive sexuality and indeed does all he can to deconstruct the heterosexual family.
\end{abstract}

Keywords: experience, numinous, queerness, sacrifice, transgression

\section{The Experience of Art}

Content of spiritual significance may be uncovered, at times, in the most unlikeliest of places. In this essay, I argue that the trash neo-slasher film Headless may be viewed as one such instance, provided we introduce a suitable hermeneutic dimension to the equation. What Cleanth Brooks writes of poetry may also be said to be true of any particular art form: "the poem is a dramatization, not a formula; a controlled experience which has to be experienced, not a logical process." (Brooks, 1960, p. 174.) Similarly to a poem, the content conveyed by Headless must be experienced not as a narrative to be rationally or logically explained or, worse, reduced to the psyche of its creator, but rather as an inner experience, a spiritual involvement of self-shattering intensity that allows for an opening of the subject to higher forces. Psychological explanations simply do not work in the context of this irrational realm. According to Rudolf Otto, the idea of the holy contains a "numinous" aspect, an irrational dimension that is foreclosed to direct contact. The numinous is at once a value and a "state of mind” that „cannot be strictly defined."

(c) AesthetixMS 2016. This Open Access article is published under a Creative Commons Attribution Non-Commercial 4.0 International License (http://creativecommons.org/licenses/by-nc/4.o/), which permits non-commercial re-use, distribution, and reproduction in any medium, provided the original work is properly cited. For citation use the DOI. For commercial re-use, please contact editor@rupkatha.com. 
(Otto, 1936, p. 7.) Religious feeling, claims Otto, is rooted in a primordial sense of dread. It is when dread is transformed into "awe" that religious feeling proper develops. (Otto, p. 14-5.)

Rather than reading Otto's hypothesis in an anthropological manner or as some misguided, empirically unfounded religious historical generalization, I propose that we read it symbolically, as the film in question unveils a numinous dimension of religiosity, in the form of a disarticulated, primeval spirituality that resists all forms of definition. Indeed, I view the muteness of the killer as constituting an apt symbol of numinous religiosity. The anonymous mute killer is a sinthomosexual, in the sense of the word used by Lee Edelman, a transgressive, malignant queer agent who puts an end to both convention and life. (Edelman, 2004) Yet the sinthomosexual can never fully articulate his or her frightful actions, for such unspeakable acts reside in a zone outside of language. Through their rejection of conventional, future-oriented heterosexuality, sinthomosexuals exclude themselves from productive, conservative, humanistic society. Instead of pride, their primary feeling is that of dreadful shame. In the conclusion, following Georges Bataille's lead, I seek to reconstruct an "atheology” predicated upon the ontological condition of "headlessness." To lose one's head is to participate in a left-handed spirituality without limitation, a numinous insanity whose final limit can only be approached, but never attained in its entirety.

Violence is oppressive, the result of damnable internal murmors. A terrible gurgling cough, uttered by a suffocating victim, an infernal prayer, fingering its way through the inner contents of a sickened mind: these two moments blend into an inner woundedness, in the form of a power that makes its way inward, until the two terms cannot be differentiated from one another. Once realized, the numinous state becomes, in itself, a product of the gurgling cough. With disturbing simplicity, death awaits all, in the realm of an afterwards that always precedes us. It starts to breathe, through open orifices...Such is the incipient blackened death, the ever-present future that hounds insomniacs, pessimists and monks alike. To love is to be carried away by darkwinged angels into a waking state imbued with ruined satisfaction. Everyday life, the life of surfaces, the life of convention governed by the samsaric law of birth, death and rebirth, is but a mere expression of solar generosity. Underneath the surfaces reside depths, layers of laughter waiting to be opened up. Far from any helping hand: such is the fate of those who come into contact with the outside, such is the condition of victimhood. Headless (2015), directed by Arthur Cullipher, presents us with the desolate contours of a bleak world aspiring to life and reproduction, only to be cut down by senseless murders. The film itself is presented as a "film within a film", a 1978 slasher work that was recently rediscovered. Of course this is mere show, the make-believe construction of a false context.

Prior to elucidating the contents of Headless and the left-hand spiritual implications of this bizarre work of trash horror, the hermeneutic direction of our investigation must be laid out in as transparent a manner as possible. Cleanth Brooks, one of the most influential North American aesthetes of the 2oth century, presents us with an interpretative model that may be of some use in a film studies context as well. For Brooks, the social or cultural context of a poem is secondary to the poem in itself. As Brooks states emphatically, "the unifying principle of the organization which is the poem is an attitude or complex of attitudes." (Brooks, p. 175.) Propositions or contexts are, from the standpoint of interpretation, secondary to the poem itself. Brooks uses the metaphor of dance as an illustration. When inquiring in relation to a dance, we should not ask the dancers themselves what they are doing, for to do so requires halting the dance, ruining the possibility of making a true discovery. Hence, when interpreting poetry, the poem itself must be left to its own devices by the interpreter. The work of art, be it a poem or a painting or a film, has an autonomy of its own, a self-sufficiency that should not be destroyed 
merely for the sake of over-interpretation. In the context of Headless, this entails that I am not primarily interested in issues of genre or genre context, much less the social environment that has proven hospitable for the proliferation of neo-slasher cult films such as Headless. All these points are relevant topics of study, but right now they lie outside the purview of this essay.

Brooks asserts, in no uncertain terms, "the primacy of the pattern" of the poem itself. (Brooks, p. 178.) This means that not only is the poem, as a whole, independent of its context, but also of its content. Structure as such is primary, while content is secondary. While this position is debatable and has been criticized as being overly holistic by speculative realist philosopher Graham Harman (Harman 2012, p. 249.), I want to draw attention to a particularly interesting differentiation made by Brooks with regard to the "attractiveness" of a poem: "we must draw a sharp distinction between the attractiveness or beauty of any particular item taken as such and the 'beauty' of the poem considered as a whole." (Brooks, p. 178.) Once this scission is introduced, the work of art becomes a fragmentary expression, a whole that is no longer a harmonious sum of components, but a disarticulated, destabilized structure. Harman is entirely correct when he states "just Brooks is right to split off the poem from its total socio-historical context and treat it as a partially autonomous unit, he is wrong to deny the same liberty to individual elements within the poem." (Harman, p. 249.)

Structure is marinated by images, connotations, conceptions. When a glowing light creeps up on us, our senses become desexualized by an inner tenebruousness, only to be resexualized by the presence of the masochistically-recluding object of desire. As we shall see, the dual movement of desexualization and resexualization is enacted in Headless by the psychotically disturbed killer. The structure of a work of art is both a "principle of unity" and a unity of "meanings, evaluations and interpretations", a synthesis of perspectives. (Brooks, p. 178-9.) As distinct from the usual emphasis on themes, imagery or rhythm, Brooks situates experience at the core of poetry. Experience lies beyond even meaning. (Brooks, p. 18o.) The unity of the work of art is to be sought not in the various logical formulas or conclusions, but in the "equilibrium of forces" it achieves, encapsulated by the experience of the poet. (Brooks, p. 189.) Artworks are machines enacting themselves in the world, objects releasing inner tensions into their environments, and most defininitely cannot be reduced to assortments of sentences, propositions or paraphrases. Harman puts it brilliantly when he compares objects to "escape pods that jettison clear of their original environments, even if those environments have left certain traces (but not others) on the objects." (Harman, p. 245.)

Sometimes a drunkard collapses: this movement is that of a beheaded tyrant, a creature that has lost its access to consciousness. Writing, once revealed as originally fragmented, becomes a partially self-sufficient wreckage of life, a residue of experience that has nevertheless untethered itself from the living. Interpretation cannot be neatly separated from writing, for the "complex of attitudes achieved" forms an integral part of the overall success of a poem. (Brooks, p. 189.) This is not to say that this must be considered in the mode of a strict correlation, for autonomy entails a partial liberation from intepretative context. A good artwork creates attitudes that in turn produce situations. (Brooks, p. 191.) In Brooks' summary, the task of the poet is to introduce a new synthesis into life, a real abstraction, a simulacrum that nevertheless becomes an experience in its own right:

"his task is finally to unify experience. He must return us to the unity of the experience itself as man knows it in his own experience. The poem, if it is to be a true poem is a simulacrum from reality - in this sense, at least, it is an 'imitation' - by being an experience rather than any mere statement about experience or any mere abstraction from 
experience." (Brooks, p. 194.) If it is to attain to the status of art, an artwork must become an experience of that which it represents.

\section{Beheadings and Trysts}

Artistic intensity is achieved when the simulacrum breaks into life, like a pool of blood running across our eyes. In all fairness to Brooks, he does not state for a moment that this unity must of necessity lead us to a harmonious whole. Unity, on the level of content, can lead through momentous upheavals of disquiet. To quote Vladimir Nabokov's protagonist, Cincinnatus, "which will it be? A beheading or a tryst?" (Nabokov, 1989, p. 53.) In Headless, what we find is the simulated, albeit all too real experience of beheading becoming a tryst, the abysmal transformation of desexualizing death into resexualized perversity. Beheading, simply put, does not preclude posthumous trysts, brutally obscene ejaculations. In medias res, in the opening scene, we see a young woman brutally murdered, decapitated, her left eye gouged out with a spoon and eaten by the depraved monster, who wears a skull-mask to hide the shame of his actions. Death consumes the gaze. But it does not stop here: this monstrous individual unzips his pants and proceeds to have intercourse with the orbit that formerly contained the, by now greedily consumed eyeball. What, if anything, does the insane cruelty of the killer symbolize? As we soon discover, the origins of this sickening practice seems to be connected with a childhood trauma. Periodically, we see flashbacks of a cruel mother who kept her young son in a cage, and a sister who sexually teased her dim-witted brother.

But is this explanation really satisfactory? And why, of all bodily organs, is the serial killer obssessed with the eye? Cruelty, as Gilles Deleuze reminds us, is always tied up with deeper layers of interpretation, experiences that psychology and psychoanalytical reductivism fail to register. In his essay on Sacher-Masoch's Venus in Furs, Deleuze writes that "cruelty conceals the more secret theme of the coldness of Nature, of the steppe, of the icy image of the Mother... the coldness of the stern mother is in reality a transmutation of cruelty from which the new man emerges." (Deleuze, 1991, p. 13.) As I seek to show, to interpret the killer portrayed in Headless as a mere sadist would be a gross oversimplification. Rather, he is a masochistic product of cruelty already construed as an animal. Sadism, in Deleuze's view, is intimitaly connected with „desexualization”, a violence that expels the ego outward into the victims of violence. (Deleuze, p. 131.) Yet at its peak, desexualization culminates in "a total resexualization": for the sadist, everything is sexual, every orifice deserves to be penetrated, thrust into, pried open and pushed into. (Deleuze, p. 127.) The cruelty of the sadist - laughing while he slushes in the blackened blood of his victims, all the while comically frothing at the mouth - is a total resexualization of the dismembered corpse. Soaked in sin, the killer becomes the puppet of his own design.

In sadism, Deleuze discovers a "dual process of desexualization and resexualization" that finds expression in "the demonstrative thrust." (Deleuze, p. 128.) Not satisfied with taking his victim's heads, the killer must have intercourse with these grisly tokens, either through penetration of the orbit or the neck. Once transformed into an orifice, the open neck too becomes ready for reentry. But sadism is also connected with pain and the cruel enjoyment of scenes of ordeal. Were he a true sadist, the killer would without doubt proceed to do violence his victims while they are still alive. In this case, however, the mutilation occurs post mortem. 


\section{Numinous Experience}

The beheader in Headless dispatches his victims relatively swiftly, usually beheading them at a later point. What is the meaning of beheading in the first place? Why this need for decapitation? Although the film contains no explicit religious content, there is a scene that could be of pertinence in this regard. The killer is routinely accompanied by a small childlike figure who also wears a skull-mask, not unlike that of the killer himself. His identity remains hidden throughout. Ordinarily - and this meaning is undoubtedly implied by the script - we would be led to assume that this alter ego is none other than a personage of the killer, in a younger form. But this young child bears all the hallmarks of a demonic entity. A limitlessly bloodthirsty superego, the Accomplice - let us call him that - may be read as the hidden aspect of religiosity, a symbol of Left-Hand spirituality. As opposed to the solar, enlightened, rational luminous aspect, the LeftHand is connected with the lunar, darkened, irrational facet, as well as what Rudolf Otto terms the "numinous." It is this latter term that I want to reflect upon, before returning to the theme of headlessness and resexualization.

From whence does the demonic laughter of the killer originate? What are the spiritual sources of this murderous rampage? Surely hidden forces must be at work. The situation cannot be explained through any recourse to the killer's interiority, for however he may try, he finds himself guided by forces outside of his control. The experience of insanity drives the serial killer to continue his rampage. The numinous is irrationality itself, the aspect of religion that cannot be explained away by means of either rational theology or psychology. In dread, "the numinous shows itself." (Otto, p. 16.) When we say that something "made my blood run cold", there is already an element of the supernatural at work. When the flesh decides to unveil itself, all images fail and the body is presented with its own outside. As Otto suggests, "there is something nonnatural or supernatural about the symptom of 'creeping flesh." (Ibid.) There is something nonnatural in the terrifying acts perpetrated by this beheader of women, we just cannot seem to quite put our finger on it. Supernatural dread, as opposed to natural fear, has, in Otto's view, a qualitative dimension that cannot be reduced to a mere question of intensity. From dread, the numinous is born. Fear of God entails an irrational dimension that precedes the descriptive efforts of theologians. (Otto, p. 19.) Religious experience is a tremendum, rather than a mere tremor. When confronted with the icon, the image of a plenitude whose power infinitely surpasses our own, we are left in darkness. Our movements become those of dethroned, executed kings slumping into the dust, or beheaded tyrants whose names have become mere expressions within history books. There is a kind of overpowering that is informed by "the feeling of one's own abasement, of being but 'dust and ashes' and nothingness." (Otto, p. 20.)

Self-abasement, at first, would seem to be rather distant from sadistic violence. But in his self-denial of rapacious sexual access to the women he murders and consumes, the killer practices a form of perverse asceticism. He has no use for these unfortunate women while they are alive. In one scene, for instance, the killer picks up an evidently flirtatious hitchhiker who unmistakably indicates her willingness for voluntary intercourse. While alive, she is uninteresting. All that matters is the satiation of the bloodthirsty demon that the killer serves. While driving, the Accomplice indicates to him that this young lady too must be sacrificed. For the killer, sacrifice itself appears to be the numinous object of desire. The living women he encounters are desexualized puppets conditioned to die, raw materials destined for an abominable processing. As opposed to the living, the ghost demands continuous murder to please his appetite. Otto identifies another element of the numinous object: its "urgency or energy." (Otto, p. 23.) The energy of the death drive, in the case of the sadist and masochist alike, overwhelms the demands 
of reproductive sexuality. In sadism, the death drives allows the ego to become „unrestrained”, amoral. (Deleuze, p. 131.) The dam of self-limitations, taboos and restrictions bursts: sin runs amok, along with the killer, who screaming and baying like a dog, runs after the doomed hitchhiker. Death and sacrifice, in Headless, come to function as truly mysterious objects. We as viewers are never really informed as to what forces drive the murderer on his sick escapades. His practice is truly mysterious in the sense that it is "beyond our apprehension and comprehension... in it we come upon something inherently 'wholly other."' (Otto, p. 28.) Rational or psychological explanation cannot come to terms with the numinous experience of slaughter.

Our sides ache in excrutiation upon seeing the remnants of past crimes. The killer finally catches up with his victim in a ditch filled with what amount to perhaps several dozen dismembered bodies. In a particularly powerful and animalistic scene, he dispatches her with one fell swoop, cutting off her head with a machete. Enveloped by the absolute otherness of death, we almost suffocate from the stench of this blood-filled abyss. It is almost as if we could lick the rotted blood from the dirty ground, so vivid is the gruesomeness of the scene. Mystery is inseparably connected with awefulness. (Otto, p. 25.) In an age that prides itself on its supposed civility and its sensitivity to the rights of a multitude of "others", the very mention of such a connection between the awe-inspiring and the aweful counts as a scandalous transgression of scholarly propriety. Indeed, Rudolf Otto himself as a Protestant theologian would undoubtedly be scandalized by such a flagrant misuse of his notion of the "numinous." Suffice it to say that the elements of a work of art, or - for that matter - any work, are in themselves also objects, selfsufficient moments that may become detached from the event that constitutes the holistic structure.

Supplementing Brooks' interesting distinction between the attractiveness of the poem's components and the allure exerted by the structure of the poem itself, I would here introduce Otto's distinction between "natural” and „numinous” consciousness. (Otto, p. 28.) Just as the experience of the poet is separated from everyday life via the institution of poetic language, so the inner experience of the murderer is separated from natural, everyday intuition. In numinous experience, the "daunting" and the "fascinating" interbreed. (Otto, p. 31.) We may find the actions of the murderer daunting, even aesthetically fascinating, without finding this aesthetic experience to be something schizophrenic or incoherent. Often the most fascinating moments are those that are the most intensely terrifying, hence the allure of horror films in general. Covered in the deep space of slaughter, we ourselves can come into contact with the terrifying allure of death. Sacrifice, in the context of this fictional serial-killing, becomes a self-referentiality that cannot be closed. Similarly, in religious experience, "to remain in these strange and bizarre states of numinous possession becomes a good in itself." (Otto, p. 33.) When not engaged in decapitation, life for the killer is an agony. This is perhaps what makes Headless stand out from many other slasher films. Instead of being offered a one-dimensional rendition of a maniacal, single-minded killer, we as viewers are fortunate enough to experience his own moments of weakness and agony. We too, in other words, are permitted to sadistically enjoy the vision of his tortured, howling existence. The numinous cannot be transmitted through written communication. Rather, "it must be 'awakened' from the spirit." (Otto, p. 62.) Even the smallest of impulses are enough to awaken the thirst for blood, let alone the abhorrent abuse meted out to the protagonist during his traumatic childhood years. Sensation, even in the context of such an admittedly inane film such as Headless, constitutes the object of horror.

As Carol J. Clover writes in her classic study of gender in slasher films, „the target is... the body, our witnessing body. But what we witness is also the body, another's body, in experience: 
the body in sex and the body in threat." (Clover, 1987, p. 189.) Experience, in Clover's view, including the experience of horror, is always already sensual. Yet Otto is quite emphatic in his assertion that the numinous cannot be represented in any positive manner. Instead, it may be approached, if never directly apprehended, by "darkness and silence." (Otto, p. 69.) A common theme of slasher films is arrested development. Protagonists are routinely depicted as males in their twenties who are childish, and incapable of adult relationships, products of the "sick family." (Clover, p. 194-5.) Sickness, it would seem, pervades the heterosexual family. As we have seen, Headless proves no exception to this classical genre convention. Although I did make the claim at the beginning of this essay that I would not pay too much attention to broader, genre concerns, it is no exaggeration to say that Headless is filled with standard, 1970s cliches. One such cliche is the selection of victims: almost invariably, the young women killed are physically attractive, often transgressive and promiscuous types. (Clover, p. 199.) In addition, the slasher as genre is animated by "a fascination with flesh or meat itself as that which is hidden from view." (Clover, p. 198.) Undoubtedly, it is this latter type of sexualizd fascination that may be identified as contituting the hidden, spiritual core of Headless. However demented he may seem, the killer has a deep spiritual affinity with that which is ordinarily hidden from view. These murders are sacrifices in the religious sense of the word.

\section{The End of Heterosexuality and the Revelation of the Beast}

In his excitement, the killer strives to unveil the flesh, spilling blood from deep within the bodies of his victims. The concluding scene also shows the sinthomosexual nature of this beast. Not only is the serial killer a transgressor of bodily boundaries, he is also a sinthomosexual, an agent that would "assert itself... against futurity, against propagation." (Edelman, p. 33.) Lee Edelman identifies fantasy as constituting the protective mechanism of a social reality intent upon propagating and maintaining itself. Fantasy is the false promise of a reality that can never be ours, an ever-present unreality seeking to blind us to the impossibility of transcending our own future absence. (Edelman, p. 34.) Sinthomosexuality would constitute a radical, intensive rejection of this promised future, an insistence upon "access to jouissance in place of access to sense, on identification with one's sinthome instead of belief in its meaning." (Edelman, p. 37.) The Lacanian notion of the "sinthome" denotes a symptom that serves as a channel for desire. Edelman's wordplay, sinthomosexual, would denote a non-reproductive sexual practice that simply enjoys whatever perversions it happens to produce, without caring for the reproduction of any social future or future generations.

Sinthomosexuality is the realization of an „unthinking jouissance” that threatens to render the very prospect of reproduction unthinkable. (Edelman, p. 39.) Broadly speaking, a sinthomosexual is any agent, fictional or real, who demonstrats an "unwillingness to contribute to the communal realization of futurity." (Edelman, p. 44-5.) The recklessness of the sinthomosexual's enjoyment forecloses heterosexual reproduction. This moment of carelessness is achieved in the nightmarish concluding scene of Headless, a vision that could even be called Satanic. Continuing his sick rampage, the killer abducts a young pair and proceeds to lacerate their exposed bodies. Grabbing the scrotum of the boyfriend, he castrates the unfortunate man with violent abandon. The sinthomosexual foreclosure of reproduction could not be stated in less uncertain terms. Not only are the two genders separated, rendered mutually inaccessible to one another, but also the mere prospect of propagation is violently destroyed with the thrust of a blade. The resemblance of the castrated boyfriend, wearing as he does long hair reminiscent of 1970 s fashion, to renditions of Jesus Christ is enough to bring this castration into association with 
the mutilation and torture of God. In one frame, the anguished boyfriend even appears to be endowed with a halo. The sinthomosexual, because he introduces death and castration into the life of the heterosexual family, must of necessity be reviled as a queer, impure creature, a filthy rat deserving of destruction. (Edelman, p. 45.) Yet the pair slated for murder already constitutes a disharmonious unity, for the girlfriend has been visibly parasitized by her lazy boyfriend. Hence the castration appears as an exaggerated, obscene punishment for the sins of an impure God, unjustly idolized by a misguided Mary Magdalene.

What as at issue in symbolic beheading? The final step downward leads us to a universe bereft of both futurity and meaning. This is a beheaded Cosmos, a world without Logos. In a feverish 1936 essay, Georges Bataille introduces the figure of Acephale, a strange beheaded being symbolizing the new age of "atheology", wherein belief in both Man and God is destroyed. As Bataille writes evocatively and with characteristic flair,

"beyond what I am, I meet a being who makes me laugh because he is headless; this fills me with dread because he is made of innocence and crime; he holds a steel weapon in his left hand, flames like those of a Sacred Heart in his right. He reunites in the same eruption Birth and Death. He is not a man. He is not a god either." (Bataille, 1985, p. 181.)

Is the killer of Headless really a man, or is he Acephale himself, the headless godman concocted by Bataille and reincarnated in a 2015 slasher film? This much we do know: the serial killer most definitely manages to reunite both death and life in a single ejaculation, and he is most certainly headless, in the sense that he has lost his grip on reality. Or is his reality a place of access to the unspeakable? Between the divine and the human, there resides the monster, unaware of any prohibitions. Leon Marvell connects Acephale, this living, beheaded divine corpse whose monstrosity nevertheless provokes uncontrollable laughter, with the occult figure of Baphomet as the "mysterious, ultimate emblem" of hidden spirituality. (Marvell, 2014, 69.) Whatever truth lies in this admittedly quite far- fetched assertion, we must be aware that at the far limits of unspeakability, there resides an abominable truth: Underneath all flesh, there is Chaos.

\section{References}

Bataille, G. (1936). The Sacred Conspiracy. trans. A. Stoekl. In. A. Stoekl (Ed. 1985), Visions of Excess. Georges Bataille. Selected Writings. Minneapolis and London: University of Minnesota Press. 178-182.

Brooks, C. (1960). The Well Wrought Urn. Studies in the Structure of Poetry. London: Dennis Dobson.

Clover, C.J. (1987) Her body, himself: Gender in the slasher film. Representations 20, 187-228.

Cullipher, A. (2015) [film] Headless. Kansas City: Slaughter Moviehouse.

Deleuze, G. (1991) Coldness and Cruelty. trans. J. McNeil. New York: Zone Books.

Edelman, L. (2004) No Future. Queer Theory and the Death Drive. Durham and London: Duke University Press.

Harman, G. (2012) Weird Realism. Lovecraft and Philosophy. Washington and Winchester: Zero Books.

Marvell, L. (2014) Headless and Unborn, or the Baphomet Restored Interfering with Bataille and Masson's Image of the Acephale. Leonardo Electronic Almanac. 20.2, 60-72.

Otto, R. (1936) The Idea of the Holy. An Inquiry into the Non-Rational Factor in the Idea of the Divine and its Relation to the Rational. trans. J. W. Harvey. London: Oxford University Press.

Nabokov, V. (1989) Invitation to a Beheading. trans. D. Nabokov. New York: Vintage Books. 